\title{
İçsel ve dişsal Covid-19 korkusunun uzaktan calışmanın faydası üzerindeki etkileri: Türk finans sektöründen bir örnek
}

\author{
Effects of internal and external covid-19 fear on the benefit of \\ teleworking: an example from the Turkish finance sector
}

\section{Ercan Özen ${ }^{1}$ \\ Bahattin Hamarat $^{2}$ \\ 1 Doç. Dr., Uşak Üniversitesi, Uygulamalı Bilimler Fakültesi, Finans ve Bankacılık Bölümü, Uşak, Türkiye, e-mail: ercan.ozen@usak.edu.tr 2 Öğr. Gör., Çanakkale Onsekiz Mart Üniversitesi, Turizm Fakültesi, Çanakkale, Türkiye, e-mail: bhamarat@comu.edu.tr}

Öz

2020 yılı başında salgına neden olan Covid-19 virüsü tüm dünyada korkuya neden olmuş, ekonomik ve sosyal yaşam üzerinde derin izler bırakmıştır. Bu çalışmada, finans sektöründe çalışanların Covid-19 korku düzeyi ile uzaktan çalışmadan algıladıkları fayda düzeyi arasındaki bağlantı incelenmekte ve çalışanlara ilişkin demografik faktörlerin algılanan fayda üzerinde farklılık yaratıp yaratmadı̆̆ı araştırılmaktadır. 458 finans sektör çalışanı ile yapılan çevrim içi anket uygulamasından elde edilen veriler CHAID yöntemi ile analiz edilmiştir. Bulgular, finans sektör çalışanlarının Covid-19 korku düzeyinin yüksek olduğunu, artan Covid-19 korku ile birlikte uzaktan çalışmanın algılanan faydasının arttığına işaret etmektedir. Ancak, uzaktan çalışmanın faydasını yüksek bulanların oranının, faydayı düşük bulanlara göre gözle görülür biçimde belirgin olmadığı anlaşılmaktadır. Uzaktan çalışmanın algılanan faydasının demografik özelliklere göre farklılaşmakta olduğu görülmüş ve uzaktan çalışmanın kalıcı olması konusunda yeterli destek oluşmadığ anlaşılmıştır. Bulgular, finans sektörü ile politika yapıcılar ve akademisyenler için veri oluşturacak sonuçlar içermektedir.

Anahtar kelimeler: Covid-19 korkusu, uzaktan çalışma, finans sektörü çalışanları, CHAID analizi

JEL kodlar1: G21, J08, D91

\begin{abstract}
The Covid-19 virus, which caused an epidemic at the beginning of 2020, caused fear all over the world and left deep impacts on economic and social life. In this study, the relationship between the level of Covid-19 fear and the level of benefit, employees perceive from tele working is examined and it is investigated whether the demographic factors of the employees make a difference on the perceived benefit. The data obtained from the online survey conducted with 458 finance sector employees were analyzed by the CHAID method. The findings indicate that the level of Covid-19 fear of financial sector employees is high, and the perceived benefit of teleworking has increased the Covid-19 fear. However, it is understood that the rate of those who think the benefit of teleworking is high, is not visibly significant compared to those who think the benefits of teleworking is low. It has been observed that the perceived benefit of teleworking differs according to demographic characteristics, and it has been understood that there is not enough support for the permanence of tele-working. The findings of the paper have some implications the financial sector, policy makers and academics.
\end{abstract}

Keywords: Fear of Covid-19, tele-working, finance industry workers, CHAID analysis

JEL codes: G21, J08, D91

Citation/Atıf: ÖZEN, E. \& HAMARAT, B., (2021). İçsel ve dışsal Covid-19 korkusunun uzaktan calışmanın faydası üzerindeki etkileri: Türk finans sektöründen bir örnek. Journal of Life Economics. 8(4): 547-554, DOI: $10.15637 /$ jlecon.8.4.13

Bu derginin içeriŏi Creative Commons Attribution-NonCommercial 4.0 Uluslararası Lisansı altında lisanslanmıştır.

Content of this journal is licensed under a Creative Common Attribution-NonCommercial 4.0 International License. 


\section{GİRIŞ}

Yeni Koronavirüs Hastalığı (COVID-19), ilk olarak 2019 yılında Aralık ayının sonlarında Çin'in Vuhan Eyaleti'nde ortaya çıkmıştır. Virüsün diğer virüslerden farkı, hızlı bir şekilde insanlar arasında yayılması ve bulaşması ile tüm ülkeleri tehdit etmesidir. Virüsün önemli bir özelliği de virüsün doğrudan temas olmaksızın hava yoluyla da bulaşmasıdır. Bu yayılma ve bulaşma sonucunda 11 Mart 2020 tarihinde Dünya Sağlık Örgütü (WHO) pandemi (salgın) ilan etmiştir.

COVID-19 virüsünün bu özelliklerinden dolayı insanların gerek açık alanlarda veya özellikle kapalı alanlarda bir araya gelmesi virüsün bulaşması ve kişilerin hastalanması sonucunda örgütlerde birlikte çalışma tehlikeli hale gelmiştir. Bunun sonucu olarak insanlar iş dünyasında birbirinden uzak işgörmek zorunda kalmıştır. çalışanların birbirine uzak çalışmaları, hastalığı veya virüsün bulaşmasını engelleyememiş ve pek çok işyeri geçici olarak kapanmıştır. Kimi örgütler bu süreçte çalışanlarına uzaktan çalışma olanakları sağlamışlardır. Uzaktan çalışma olanakları sağlanmasına rağmen kişilerin ihtiyaçların sağlanmasında olanaksızlıklar, kaygı ve korkular yaşanmıştır. Bozkurt (2020) çalışmasında bu korkuyu yaşayanların oranını \% 40 olarak belirlemiş ve dijital teknolojilerin yoğun olarak kullanıldığı sektörlerde çalışanların kaygılarının daha düşük olduğunu belirlemiştir. Pandemi döneminde, teknoloji kullanımında öncü sektörler arasında yer alan finans sektöründeki işyerlerinde ise çalışma saatleri kısıtlanmış ve dönüşümlü çalışma başlamıştır. Pandemi'nin kısa sürede biteceğine dair belirsizlik nedeniyle finansal kurumlar hızlı biçimde uzaktan hizmet verme kapasitelerini artırma refleksi göstermiştir. Son yıllarda dijitalleşmede yaşanan artış, pandemi ile birlikte daha da ivme kazanmıştır. Finansal hizmetlerde belirli ölçüde somut mal hizmet sunumundan uzaklaşma eğiliminin artması, finansal kurumların hizmetlerini ofis dışından sağlamalarını kolaylaştırmıştır. Bunun sonucu olarak finansal kurumlar, pandemi boyunca kısmen ve/veya sürekli olarak uzaktan çalışma yöntemini uygulamışlardır.

Uzaktan çalışma, çalışanlar için esneklik gibi bazı avantajlar sağlamaktadır (Özen vd, 2021). Ayrıca, çalışanların işyerine ulaşım için harcanan zamandan ve maliyetten tasarruf gibi faydaları da yapısında barındirmaktadır (Nguyen 2021). Bununla birlikte sosyal ilişkilerden mahrum kalma gibi olumsuz bazı ruhsal sorunları da beraberinde getirmektedir. Diğer taraftan, bireylerin evlerinin iyi bir çalışma ortamı olmayacağı, çalışma verimliliği için özel donanıma sahip ofislerin gerektiğini vurgulanmaktadır (Bilginoğlu, 2021). Bu durumda çalışanların uzaktan çalışma tercihleri, uzaktan çalışmanın algılanan faydası ile olumsuz ruh hali veya diğer olumsuzluklardan hangisinin baskın olacağına bağlıdır. Algılanan fayda arttıkça uzaktan çalışma tercihi artacaktır.
Doğan ve Düzel'e (2020) araştırmasına göre bireyler Covid-19 döneminde kalabalık ortamlardan kaçınma eğilimindedir ve \% 90'ından fazlası virüs kapmaktan ve virüs bulaştırmaktan korkmaktadırlar. Bu korkular nedeniyle hem işverenler hem de işgörenler uzaktan çalışmayı zorunlu bir seçenek olarak görmektedir.

Covid-19 korkusunun etkileri ile ilgili olarak mevcut literatür çok yeni ve sınırlı sayıdadır. Satıcı vd (2020)'ye göre, Covid 19 korkusunun stres ve yaşam doyumu üzerinde olumsuz etkileri olduğunu belirlenmiştir. Diğer salgınlarda olduğu gibi Covid-19 pandemisi sırasında da bireyler enfekte olma, akraba ve arkadaşlarına virüs bulaştırma ve ölüm korkusu yaşamaktadır (Doğan ve Düzel, 2020; Ladikli vd, 2020). Nguyen (2021) Vietnam'da 2020 yılı Nisan ayında yaptığ 1 araştırmada, bireylerin Covid-19'dan duydukları korku düzeyinin uzaktan çalışmayı olumlu etkilediğini ancak, işe odaklanma ve işle ilgili verilere erişimin kısıtlanmasının önemli bir zorluk olduğunu belirlemiştir. Buna göre, çalışanların Covid-19 korku düzeyindeki artış uzaktan çalışmanın algılanan faydasını arttırmalıdır. Bu durumda dolaylı olarak Covid-19 korku düzeyi yüksek olan bireylerin uzaktan çalışmayı tercih edecekleri beklenebilir. Bu durumda çalışmanın araştırma soruları şu biçimde ifade edilebilir: (i) Çalışanlar Covid-19'dan ne ölçüde korkmaktadır? (ii) Çalışanlar uzaktan çalışmadan ne ölçüde fayda sağlamaktadır? (iii) Covid-19 korku düzeyi ile algılanan fayda ve uzaktan çalışma arasında ne gibi bir ilişki bulunmaktadır? (iv) çalışanlarda uzaktan çalışmaya yönelik fayda algısına etki eden değişkenler nelerdir? (v) Çalışmanın açıklanmaya çalışılan uzaktan çalışmaya yönelik fayda değişkenini etkileyen bağımsız değişkenler arasındaki ilişkiler, etkilenmeler nasıl oluşmaktadır? (vi) Uzaktan çalışma finans sektöründe kalıcı bir hale dönüşebilir mi? Araştırmada bu soruların yanıtları araştırılmıştır.

\section{YÖNTEM}

Türk finansal hizmetler sektöründe çalışan bireylerin Covid-19 salgınının yarattığı korkunun ve çalışanların kategorik özelliklerinin uzaktan çalışmanın algılanan faydasına etkileri ve bu fayda algısının bazı kategorik özelliklere göre istatistiksel olarak anlamlı farklılık gösterip göstermediği araştırılmıştır. Ayrıca korku değişkenleri ile kategorik değişkenler arasındaki etkiler de belirlenmeye çalışılmıştır. Değişkenler arasındaki ilişkiler veya etkiler CHAID analizi ile araştırılmıştır.

Araştırmanın verileri, Türk finansal hizmetler sektöründe çalışan bireylerden anket tekniği ile çevrim içi olarak toplanmıştır. Anket formu finans çalışanlarının üye olduğu sosyal medya mecralarında paylaşılmış ve ayrıca finansal kurumlarda çalışanların formu kendi bireysel ağlarında paylaşmaları sağlanmıştır. Bu sayede 458 geçerli örneklem elde edilmiştir. Anket formu üç bölümden oluşmaktadır. İlk bölümde Türk finansal 
hizmetler sektöründe yer alan bireylerin özellikleri, ikinci bölümde ise Türk finansal hizmetler sektöründe yer alan bireylerin salgından kaynaklı korkuları ve salgından dolayı uzaktan çalışmaya yönelik fayda algılamalarını sorgulayan ve beş noktalı yanıtlardan oluşan ifadeler yer almaktadır. İfadelere verilen yanıtlar beşe yaklaşırken korkular ve fayda algısı artmaktadır. Covid-19 korkusu ve fayda algısı ölçeklerinin hazırlanmasında başta Doğan ve Düzel (2020) ile Ladikli vd.(2020) olmak üzere diğer literatürden faydalanılmıştır.

\section{BULGULAR}

Araştırma, Türk finansal hizmetler sektöründe görev alan 458 birey üzerinde gerçekleştirilmiştir. Örneklemin \% 51,3'ü kadın, \% 48,7'si erkek bireylerden oluşmaktadır. Bireylerin \% 68,3'ü Covid-19 nedeniyle kısmen uzaktan çalışmak zorunda kalmış, \% 31,7'si ise sürekli uzaktan çalışmak zorunda kaldığını belirtmiştir. Bireylerin \% 33,4' ü 18-30 yaş aralığında bulunurken, \% 43,7'si ise 31-40 yaş aralığında olduğu belirlenmiştir. 41-50 yaş aralığında olan bireylerin oranı \% 19,2 olarak belirlenirken, \% 3,7'si ise 51 + yaşa sahip olduğu belirlenmiştir. Bireylerin \% 47,6'sının çalıştığ kurum banka iken, \% 20,5'inin aracı kurumlarda çalışmakta olduğu belirlenmiştir. Sigorta şirketlerinde çalışanların oranı ise \% 5,9 olarak belirlenmiştir. Bireylerin işyerlerindeki pozisyonlarına bakıldığında \% 26,6'sı ofis çalışanı, \% 25,5'i birim yöneticisi, \% 25,3'üu müşteri ilişkilerinde çalışmaktadır. Üst yönetici olarak çalışanların oranı ise \% 5 olarak belirlenmiştir. Elde edilen sonuçlar Tablo 1'de verilmiştir.

Tablo 1. Türk Finansal Hizmetler Sektöründe Yer Alan Bireylerin

\begin{tabular}{|c|c|c|c|c|c|c|c|}
\hline Değişken & Özellik & $\mathrm{n}$ & Yüzde & Değişken & Özellik & $\mathrm{n}$ & Yüzde \\
\hline \multirow{2}{*}{ Cinsiyet } & Kadın & 235 & 51,3 & \multirow{4}{*}{ Yaş } & $18-30$ & 153 & 33,4 \\
\hline & Erkek & 223 & 48,7 & & $31-40$ & 200 & 43,7 \\
\hline \multirow{2}{*}{$\begin{array}{l}\text { Uzaktan } \\
\text { çalışma }\end{array}$} & Kismen & 313 & 68,3 & & $41-50$ & 88 & 19,2 \\
\hline & Sürekli & 145 & 31,7 & & $51-+$ & 17 & 3,7 \\
\hline \multirow{7}{*}{$\begin{array}{l}\text { Çalıştığınız } \\
\text { kurum türü }\end{array}$} & Banka & 218 & 47,6 & \multirow{7}{*}{$\begin{array}{c}\text { İşyerindeki } \\
\text { Pozisyonunuz }\end{array}$} & Ofis çalışanı & 122 & 26,6 \\
\hline & Sigorta şirketi & 27 & 5,9 & & $\begin{array}{c}\text { Birim } \\
\text { yöneticisi }\end{array}$ & 117 & 25,5 \\
\hline & Aracı kurum & 94 & 20,5 & & Üst yönetici & 23 & 5,0 \\
\hline & $\begin{array}{c}\text { Kendi adına } \\
\text { çalışan }\end{array}$ & 13 & 2,8 & & $\begin{array}{l}\text { İcra kurulu } \\
\text { üyesi }\end{array}$ & 3 & 0,7 \\
\hline & $\begin{array}{c}\text { Kamu finansal } \\
\text { kurum }\end{array}$ & 13 & 2,8 & & $\begin{array}{l}\text { Müşteri } \\
\text { ilişkileri }\end{array}$ & 116 & 25,3 \\
\hline & $\begin{array}{c}\text { Diğer finansal } \\
\text { kurumlar }\end{array}$ & 39 & 8,5 & & $\begin{array}{c}\text { Teknik destek } \\
\text { elemanı }\end{array}$ & 4 & 0,9 \\
\hline & Diğger & 54 & 11,8 & & Diğer & 73 & 15,9 \\
\hline
\end{tabular}

Araştırmada ölçeklerde yer alan ifadeler literatürden ve uzman görüşlerinden yararlanılarak hazırlanmıştır. Öncelikle ölçeklerin ortak faktör yapıları keşfedici faktör analizi ile incelenmiştir. Yöntem olarak Temel Bileşenler Yöntemi tercih edilmiş, rotasyon için Varimax yöntemi esas alınmıştır. Faktör analizi yapabilmek için örneklem yeterliliği Kaiser-Meyer-Olkin (KMO) ölçüsü ile değerlendirilmiş ve KMO değeri 0,837 bulunmuştur. Dolayısıyla veri matrisi faktör analizi yapabilmek için örneklem yeterliliğine sahiptir. Faktör yükleri matrisini hesaplarken kullanılan korelasyon matrisinin birim matris olup olmadığ 1 Bartlett test istatistiği ile incelenmiş ve istatistik anlamlı bulunmuştur (Approx. Chi-Square=4325,886 p=0,000). 
Keşfedici faktör analizi sonucunda özdeğeri birden büyük üç faktör belirlenmiştir. Faktörler toplam varyansın \% 77,607'sini açıklamaktadır. Toplam varyansin \% 43,23'ünü açılayan birinci faktör Covid-19 nedeniyle uzaktan çalışmak zorunda kalmanın faydaları olarak isimlendirilmiştir. Toplam varyansın \% 18,608'ini açıllayan ikinci faktör ise içe dönük korkular olarak isimlendirilirken son faktör ise dışa dönük korkular olarak isimlendirilmiştir. Son faktör toplam varyansın \% 15,769'unu açıklamaktadır. Ölçekte yer alan ifadelerin ölçekle ağırlıklarına bakıldığında $\left(\mathrm{h}^{2}\right)$ 0,600 ile 0,927 arasında değiştiği ve ölçekten çıkarmayı gerektiren herhangi bir ifadenin olmadığı belirlenmemiştir. Faktör analizi sonucunda elde edilen ortak faktör yapılarının güvenirlik analizleri Cronbach's Alpha istatistiği ile araştırılmış ve Cronbach'sAlpha istatistiğinin 0,819 ile 0,941 arasında yer aldığı belirlenmiştir. Faktörlerin ortalamaları ise 3,371 ile 4,641 arasında yer aldığı belirlenmiştir. Faktör analizi sonuçları Tablo 2'de verilmiştir.

Tablo 2. Faktör Analizi Sonuçları

\begin{tabular}{|c|c|c|c|c|}
\hline & \multirow[b]{2}{*}{$\mathrm{h}^{2}$} & \multicolumn{3}{|c|}{ Faktörler } \\
\hline & & F1 & F2 & F3 \\
\hline Uzaktan çalışma verimli çalışabilmemi sağlar & 0,828 & 0,907 & & \\
\hline Uzaktan çalışma daha iyi bir yaşam kalitesi sağlar & 0,819 & 0,903 & & \\
\hline Uzaktan çalışma daha çok iş üretmemi sağlar & 0,771 & 0,877 & & \\
\hline Uzaktan çalışma daha iyi bir yaşam dengesi sağlar & 0,744 & 0,862 & & \\
\hline Uzaktan çalışma kendi zaman yönetimimi yapabilmemi sağlar & 0,746 & 0,857 & & \\
\hline Uzaktan çalışma bağımsız çalışabilme imkanı verir & 0,708 & 0,837 & & \\
\hline Uzaktan çalışma esnek çalışabilme sağlar & 0,600 & 0,759 & & \\
\hline Covid hastası olmaktan korkarım & 0,801 & & 0,882 & \\
\hline Karantinada kalmaktan korkarım & 0,745 & & 0,859 & \\
\hline Covid nedeniyle ölmekten korkarım & 0,699 & & 0,771 & \\
\hline Sevdiklerime covid bulaştırmaktan korkarım & 0,927 & & & 0,942 \\
\hline İș arkadaşlarıma covid bulaștırmaktan korkarım & 0,926 & & & 0,935 \\
\hline & $\mathrm{KMO}$ & 0,837 & & \\
\hline Bartle & istatistiği & 4325,9 & & \\
\hline & Özdeğer & 5,188 & 2,233 & 1,892 \\
\hline & in varyans & 43,230 & 18,608 & 15,769 \\
\hline Açıklanan bi & li varyans & 43,230 & 61,838 & 77,607 \\
\hline & ch's Alpha & 0,941 & 0,819 & 0,924 \\
\hline & Ortalama & 3,371 & 3,785 & 4,641 \\
\hline
\end{tabular}

Keşfedici nitelikte faktör analizi ile elde edilen üç faktörde yer alan ifadeler doğrulayıcı nitelikte olan doğrulayıcı faktör analizi ile incelenmiştir. Doğrulayıcı faktör analizi LISREL 8.8 ve Smart-PLS V.3.3.3 yazılımları ile gerçekleştirilmiştir. Doğrulayıcı Faktör analizi sonucunda bağımsız değişkenler arasında doğrusal çoklu bağınt1 sorununa rastlanmıştır. Fayda boyutunda "Uzaktan çalışma verimli çalışabilmemi sağlar" ifadesi (VIF=6,531 hesaplanmış), çoklu doğrusal bağıntıya neden olduğu belirlenmiş ve ölçekten çıkartılmıştır. Lisrel yazılımından elde edilen uyum ölçülerinde 2 /sd ile RMSEA değerleri kabul edilebilir uyumu gösterirken diğer uyum ölçüleri iyi uyumu göstermektedir. Elde edilen sonuçlar Tablo 3'de verilmiştir.

Tablo 3. Keşfedici Faktör Analizi ile Elde Edilen Boyutlara Yönelik

\begin{tabular}{|c|c|c|c|c|c|c|c|c|}
\hline Model & $\chi^{2} / \mathbf{s d}$ & RMSËA & SRMR & NNFI & NFI & CFI & IFI & GFI \\
\hline Ölçüm Modeli & 3,67 & 0,077 & 0.037 & 0,97 & 0,97 & 0,98 & 0,98 & 0,95 \\
\hline Teorik değer & $\leq 5^{* *}$ & $\leq 0.08^{* *}$ & $\leq 0.05^{*}$ & $\geq 0.95^{*}$ & $\geq 0.95^{*}$ & $\geq 0.95^{*}$ & $\geq 0.95^{*}$ & $\geq 0.95^{*}$ \\
\hline
\end{tabular}

*'yi uyum. ${ }^{* *}$ Kabul edilebilir uyum 
Keşfedici faktör analizi ile elde edilen boyutların iç tutarlılık güvenirlikleri, birleşme geçerliliği ve ayrışma geçerlilikleri Smart PLS ile incelenmiştir. İç tutarlılıkları Cronbach's Alpha, Composite Reliability ve rho_A değerleri eşik değer olan 0,70'değerinden daha yüksek hesaplandığından ölçeklerin iç güvenirlikleri sağlanmıştır. Birleşme geçerliliği için AVE (Averrage Variance Extracted) değeri dikkate alınmıştır. AVE değeri uyuşum geçerliliğini vermektedir. Modelde uyuşum (Birleşme) geçerliliğinin sağlanabilmesi için AVE değerinin eşik değer olan 0,50'den daha yüksek olması gerekmektedir. Araştırmada bu kriter sağlanmıştır. Ayrışma geçerliliği için Fornell-Larcker ölçütüne ve HTMT (Heterotrait- Monotrait Ratio) değerlerine bakılmıştır. Fornell-Larcker ölçütü AVE değerinin karekökü olup 0,70'den büyük olmalı ve değişkenler arasındaki ilişki katsayılarından daha yüksek olması gerekmektedir. Araştırmada bu kriter de sağlanmıştır. Diğer bir ayrıştırma katsayısı HTMT değerinin 0,85 eşik değerinden daha düşük olması gerekmekte olup araştırmada bu kriter sağlanmıştır. Smart-PLS yazıl1mindan elde edilen sonuçlar Tablo 4'de verilmiştir.

Tablo 4. Araştırma Boyutlarına Yönelik Kritik Değerler

\begin{tabular}{|c|c|c|c|c|}
\hline & & DDK & Fayda & IDK \\
\hline Fornell- & D1şa dönük korkular (DDK) & 0,965 & ----- & ----- \\
\hline Larcker & Uzaktan çalışmaya yönelik fayda (Fayda) & 0,123 & $\mathbf{0 , 8 5 5}$ & ----- \\
\hline \multirow[t]{5}{*}{ Kriteri } & İçe dönük korkular (IDK) & 0,412 & 0,166 & 0,856 \\
\hline & AVE & 0,931 & 0,731 & 0,733 \\
\hline & Cronbach's Alpha(CA) & 0,926 & 0,927 & 0,821 \\
\hline & rho A & 0,930 & 0,940 & 0,854 \\
\hline & CompositeRreliability (CR) & 0,964 & 0,942 & 0,892 \\
\hline \multirow{3}{*}{ HTMT } & Dişa dönük korkular (DDK) & ----- & ----- & ----- \\
\hline & Uzaktan çalışmaya yönelik fayda (Fayda) & 0,129 & ----- & ----- \\
\hline & İçe dönük korkular (IDK) & 0,458 & 0,184 & ----- \\
\hline \multicolumn{2}{|r|}{ En büyük VIF değeri } & 4,035 & & \\
\hline
\end{tabular}

Türk finansal hizmetler sektöründe yer alan bireylerin Covid 19 salgın döneminde çeşitli özellikleri ile salgından kaynaklı korkuları ve uzaktan çalışmanın faydaları arasında ilişkiler Etkileşim Belirleme Analizi (CHAID) ile belirlenmiştir. Araştırmada bağımlı değişken olarak Covid-19 nedeniyle uzaktan çalışmak zorunda kalmanın faydaları değişkeni alınmıştır.

CHAID analizi çok değişkenli bir analiz olup Regresyon Ağacı veya Karar Ağacı olarak da ifade edilmektedir. CHAID analizi ile bağımlı değişkeni etkilediği varsayılan değişken ve değişken kümeleri elde edilebilmektedir. Böylelikle bireylerin Covid-19 nedeniyle uzaktan çalışmak zorunda kalmanın faydaları (Araştırmanın bu noktasından sonra fayda olarak anılacaktır) değişkenine etki eden değişken ve değişken kümeleri belirlenmiş olacaktır.

Regresyon Ağacı (CHAID) yöntemi Karar Ağaçları olarak da ifade edilmektedir. Karar Ağaçları, bir problemi oluşturan veri setlerinin yapısına göre bir ağaç yapısı şeklinde sinıflandırmaya yarayan regresyon modelleri oluşturmaktadır. Karar Ağaçları, sınıflama ve regresyon sınıflama ve regresyon probleminin çözümünde çok aşamalı ve ardışık bir yaklaşım ile karmaşık yapıdaki verileri aşamalı bir hale dönüştürerek basit bir karar verme işlemini gerçekleştirmektedir. Ağaç modellerinde bağımlı değişken kategorik yap1da olduğu durumlarda sınıflama ağacı, bağımlı değişken sürekli bir değişken olduğu durumlarda ise regresyon ağacı modeli kullanılmaktadır (Sümbüloğlu ve Akdağ, 2007).

Sınıflama ve Regresyon ağaçları bağımsız değişkene ait hiçbir ön koşul öne sürmeden kesikli ya da sürek- li bağımlı değişkenin sınıf üyeliğini tahmin etmeye yarayan ters ağaç şeklindeki modellerdir. Kategorik veya sürekli, bir ya da birden fazla bağımsız değişkenin kombinasyonları kullanılarak, tekrarlamalı ikili homojen bölünmelerle, bağımlı değişkendeki değişimi ortaya çıkarmaya ve bağımlı değişkenin değerlerini tahmin etmeye yarayan ve görsel olarak ters ağaç şeklindeki modellere ağaç modelleri denmektedir (Akşahan ve Keskin 2015).

CHAID analizinde bağımlı değişken olarak Covid-19 nedeniyle uzaktan çalışmak zorunda kalmanın faydaları değişkenini etkilediği düşünülen dişa dönük korkular, içe dönük korkular, cinsiyet, yaş ve çalış1lan kurum değişkenleri açıklayıcı değişken olarak ele alınmıştır. Araştırmada kayıp veriler dikkate alınmadan analizler gerçekleştirilmiştir. Uzaktan çalışmaya yönelik fayda, dişa dönük ve içe dönük korkular değişkenleri (0; 3] arası düşük, (3;5] arası yüksek olarak değerlendirilmiş ve değişkenler kategorik hale getirilmiştir. CHAID analizi sonucunda 3 dallanma 12 düğüm (Node) elde edilmiştir. Regresyon ağacı modelinde ilk düğümde araştırmanın bağımlı değişkeni bireylerin uzaktan çalışmaya yönelik fayda dügümü incelendiğinde 321 bireyin \% 55,8'inin fayda alg1sı yüksek olduğu belirlenmiştir. CHAID analizine göre fayda değişkenini en çok etkileyen değişken bireylerin çalıştıkları kurum türü olduğu belirlenmiştir ( $\chi 2=17,486 \mathrm{p}=0,000)$. Çalışılan kurum değişkeni iki düğüme ayrılmıştır. İlk düğümde 211 banka çalışanı (Ban) yer almakta ve bu düğümde bulunan çalışanların \% 47,4'ünün uzaktan çalışmaya yönelik fayda alg1s1 yüksek olduğu belirlenmiştir. 211 banka çalışanlarından \% 52,6'sı ise uzaktan çalışmaya yönelik fayda algısının düşük olduğu bulunmuştur. Dügüum birde 
bulunan 211 banka çalışanını etkileyen değişken dışa dönük korkuları oluşturmaktadır ( $\chi 2=10,253$ p=0,001). Dışa dönük korkular değişkeni iki düğümden oluşmaktadır. Bu düğümlerden 3'de dışa dönük korkuları yüksek olan 190 birey yer almaktadır. Bu bireylerin \% 51,1'inin uzaktan çalışmaya yönelik fayda algısının yüksek olduğu tespit edilmiştir. Uzaktan çalışmaya yönelik fayda algısı düşük olanların oranı ise \% 48,9 olarak hesaplanmıştır. Dışa dönük korkuların düşük olduğu 4. düğümünde 21 çalışan bulunmaktadır. Bu 21 çalışanın uzaktan çalışmaya yönelik fayda algısı yüksek olanların oranı \% 14,3 olarak belirlenirken, düşük fayda algısına sahip olan bireylerin oranı ise \% 85,7 olarak hesaplanmıştır. İkinci dallanmada düğüm 3 sonlanırken, dışa dönük korkuları düşük olan 21 bireyin etkilendiği değişken yaş değişkeni olduğu tespit edilmiştir ( $\chi 2=11,200 \mathrm{p}=0,002)$. Yaş değişkeni de iki düğümden oluşmaktadır. Yaşı 40 ve daha az olan düğ̈ümde 16 birey yer almakta ve bu bireylerin tamamının uzaktan çalışmaya yönelik fayda algısının düşük olduğu belirlenmiştir. Yaşı 41-50 arasında olan 5 bireyden 3 bireyin uzaktan çalışmaya yönelik fayda algısı yüksek bulunmuştur.

Çalışılan kurum, sigorta şirketi (SŞ) ve aracı kurumda çalışan 110 bireyin (Dügüum 2) uzaktan çalışmaya yönelik fayda algısı yüksek olanların oranı \% 71,8 olarak hesaplanmıştır. Uzaktan çalışmaya yönelik fayda algısı düşük olanların oranı \% 28,2 olarak belirlenmiştir. Bu düğümde bulunan 110 bireyi etkileyen değişkenin ise içe dönük korkular olduğu belirlenmiştir ( $\chi 2=4,034$ p=0,045). İçe dönük korkular dallanması iki düğümden oluşmaktadır. İçe dönük korkular dallanması yüksek olan ve dügüü 5'de yer alan 79 bireyin \% 77,2'sinin uzaktan çalışmaya yönelik fayda algısının yüksek olduğu belirlenmiştir. Ancak düğümde bulunan bireylerin \% 22,8'inin uzaktan çalışmaya yönelik fayda algısının düşük olduğu bulunmuştur. Düğüm 5'de yer alan 79 bireyin kararlarını etkileyen değişken Covid-19 döneminde uzaktan çalışma durumu oldu$\breve{g u}$ belirlenmiştir $(\chi 2=4,982 p=0,026)$. Covid-19 döneminde uzaktan çalışma durumu değişkeni üçüncü dallanmada yer almakta ve kısmen uzaktan çalışan 48 bireyin \% 68,8'inin uzaktan çalışmaya yönelik fayda algısı yüksek olarak hesaplanmıştır. Covid-19 döneminde kısmen uzaktan çalışan 48 bireyin \% 31,2'sinin uzaktan çalışmaya yönelik fayda algısı düşük olduğu belirlenmiştir. Covid-19 döneminde sürekli uzaktan çalışan 31 bireyin \% 90,3'ünün uzaktan çalışmaya yönelik fayda algısı yüksek olduğu belirlenmiştir.

İçe dönük korkuları düşük bulunan (düğüm 6) 31bireyin \% 58,1'inin uzaktan çalışmaya yönelik fayda algısı yüksek olduğu belirlenmiştir. İçe dönük korkuları düşük bulunan 31 bireyin \% 41,9'unun uzaktan çalışmaya yönelik fayda algısı düşük olduğu belirlenmiştir. İçe dönük korkuları düşük bulunan 31 bireyin kararlarında etkili olan değişkenin cinsiyet değişkeni olduğu belirlenmiştir ( $\chi 2=5,237 \mathrm{p}=0,022)$. Üçüncü dallanmada yer alan ve düğüm 11 'de yer alan 17 erkek bireyin 13 'ünün $(\% 76,5)$ uzaktan çalışmaya yönelik fayda algısı yüksek olduğu bulunmuştur. Düğümde bulunan 4 bireyin ise uzaktan çalışmaya yönelik fayda alg1sı düşük olduğu belirlenmiştir. Düğüm 12'de yer alan 14 kadın bireyin 9'nun (\% 64,3) uzaktan çalışmaya yönelik fayda algısı düşük olduğu belirlenirken, 5 kadın bireyin $(\% 35,7)$ uzaktan çalışmaya yönelik fayda algısı yüksek olduğu tespit edilmiştir. Etkilere yönelik sınıflama ağacı Grafik 1'de verilmiştir. 
Grafik 1. Covid-19 Nedeniyle Uzaktan Çalışmak Zorunda Kalmanın Faydalarını Etkilediği Düşünülen Değişkenler ve Sinıflama Grafiği

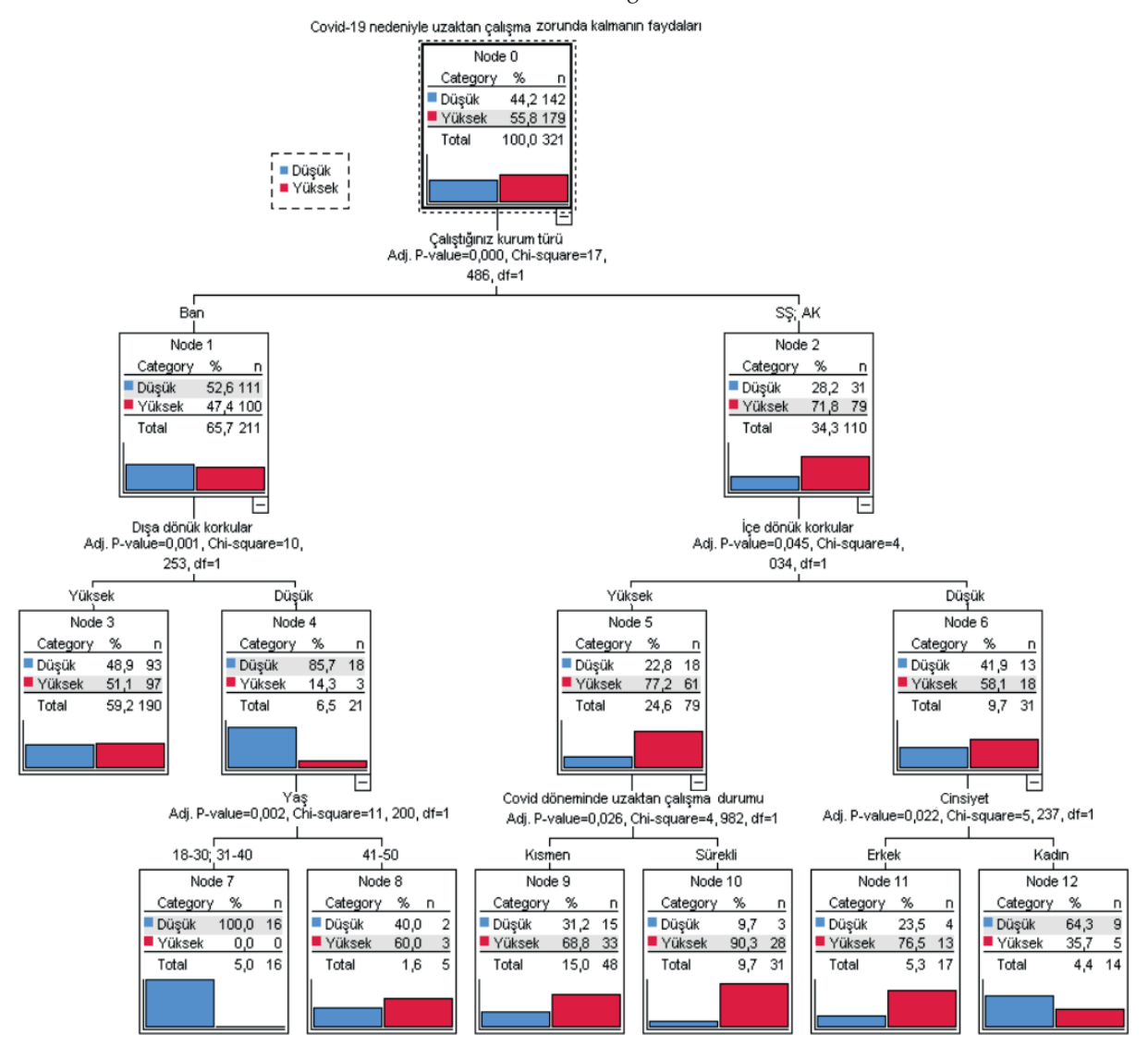

\section{SONUÇ VE DEĞERLENDİRME}

Bu çalışmanın amacı Türk finans dünyası çalışanlarının Covid-19 döneminde uzaktan çalışma uygulamalarından algıladıkları fayda düzeyinin belirlenmesi ve Covid-19 korkusunun algılanan fayda üzerindeki etki düzeyini belirlemektir. Ayrıca işyerinin türü, çalışanların yaşı, uzaktan çalışmanın sürekli veya geçici olup olmaması ile cinsiyetin uzaktan çalışmanın faydası üzerindeki etkisi ele alınmıştır.

Faktör analizine göre Covid-19 korkusu içe dönük ve dışa dönük olmak üzere iki ayrı faktör olarak ortaya çıkmıştır. Çalışma bulguları, finans sektör çalışanlarının korku düzeyleri üzerinde iş yerinin farklılık yarattığını göstermektedir. Bankacılık, sigorta sektörü ve aracı kurum çalışanlarının korku düzeyleri diğerlerine göre farklılık göstermektedir. Öncelikle, bu sektörlerde çalışanların \% 55,8'lik kısmının uzaktan çalışmadan algıladığı fayda düzeyi 3 puanın üzerindedir. Bankacılık sektöründe çalışanların uzaktan çalışmadan algıladıkları faydayı belirleyen şey dışa dönük korkudur. Buna karşılık sigortacılık ve aracı kurum (SŞ-AK) çalışanları için içe dönük korku belirleyici bir etkiye sahiptir. Bankacılık sektöründe çalışanların \% 52,6'sı uzaktan çalışmanın faydasını düşük bulmaktadır. Bunda, bankaların uzaktan çalışmayı dönüşümlü olarak uygulamaları nedeniyle çalışanların şubelerde fiili olarak bulunmalarının rolü olduğu akla gelmek- tedir. Fiili olarak ev dışına çıkan banka çalışanlarının, başkalarından virüs kaparak evde bulunan aile üyelerine virüs bulaştırma olasılığının olması bu kişilerdeki dışsal korkuyu ortaya çıkarmaktadır.

SŞ-AK çalışanlarında ise uzaktan çalışmanın faydasını yüksek bulanların oranı \%71,8'dir. Banka çalışanları ile SŞ-AK çalışanları arasında bu farklılığı ortaya çıkaran şey, iki kesimde müşteriye sunulan hizmetin farklılaşmasıdır. Bankalar müşterileri ile çek, senet, nakit TL ve döviz alım-satımı, kiralık kasa vb. işlemleri çoğu zaman fiziki olarak yapmak zorundadır. SŞAK'da ise işlemlerin çok büyük kısmının elektronik olarak yapılma olanağı bulunmaktadır.

Dışa dönük korkuları yüksek olan banka çalışanlarının \% 51,1'inin elde ettikleri fayda yüksek iken, dışa dönük korku düzeyi düşük olan çalışanların sadece \% 14,3'ü yüksek fayda elde etmektedir. Bu da, banka çalışanları arasında artan korku düzeyinin algılanan faydayı arttırdığını göstermektedir. Yaş'ın etkisine bakıldığında, 40 yaşından küçüklerin fayda algısının düşük olduğu, 40 yaş üzerinin ise, 40 yaş altındaki kişilerden daha yüksek fayda sağladığı belirlenmiştir.

İçe dönük korku düzeyi yüksek olan SŞ-AK çalışanlarının önemli bir kısmında $(\% 77,2)$ algılanan fayda düzeyi yüksektir, Düşük korku düzeyine sahip olanların bile çoğunluğu $(\%$ 58,1) uzaktan çalışmanın faydası- 
nı yüksek görmektedir. İçe dönük korkuları yüksek olanların kısmen veya sürekli olarak uzaktan çalışma yapması algılanan faydanın yüksek olmasına engel değildir. Cinsiyetin etkisi ise açık olarak görülmektedir. İçe dönük korkuları düşük olan SŞ-AK çalışanlarında; erkeklerin \%76,5'i yüksek fayda sağlarken, kadınların sadece $\% 35,7^{\prime}$ sinin algıladığı fayda yüksektir. Bu sonuç, kadınların evde iken kurumuna ait işi yapmakta iken, aynı zamanda ev işlerini de yaptıklarını ve iş yükünün azalmadığını akla getirmektedir. Bulgular hem dişa dönük korkunun hem de içe dönük korkunun uzaktan çalışmanın algılanan faydasını arttırdığını işaret etmektedir. Bu da mevcut dar literatür bulguları ile uyumludur.

Özet olarak vurgulamak gerekirse; finans sektör çalışanlarının Covid-19 korku düzeyi yüksektir. Örneklemdeki çalışanların uzaktan çalışmayı faydalı olarak görme konusunda görüş birliğinde olmadıkları görülmektedir. Algılanan fayda iş yeri türüne göre değişiklik göstermektedir. Korku düzeyinin artması algılanan faydayı arttırmaktadır. İşyeri türü ve cinsiyet, uzaktan çalışmanın algılanan fayda düzeyi üzerinde etkilidir. Uzaktan çalışmanın kalıcı hale gelmesi konusunda çalışanların yeterince istekli olduğunu söylemek söz konusu değildir.

Elde edilen bulgular, hem finansal kurum yöneticileri, çalışanlar ve kamu politika yapıcıların üretecekleri politikaları oluşturmada, hem de akademik camianın araştırmaları için veri sağlamaktadır. Çalışma sonuçları örneklemin finansal kurumlar arasında farklı dağılabilmesi nedeniyle farklılaşabilecektir. Bu da çalışmanın en önemli kısıtlarından birini oluşturmaktadır.

\section{KAYNAKÇA}

AKŞAHAN, R.\& KESKIN, İ. (2015) Sığırlarda Besi Sonu Canlı Ağırlığını Etkileyen Bazı Vücut Ölçülerinin Regresyon Ağacı Yöntemi ile Belirlenmesi. Selçuk Tarım Bilimleri Dergisi. 2(1):53-59

BILGiNOĞLU, E. (2021). Covid-19 Pandemisi Surasında Uzaktan Çalışmanın Artan Önemi: Bilinen Yanlışlar ve Doğruları. Çalışma ve Toplum, 69(2). 1099-1146.

BOZKURT, V. (2020). Working During A Pandemic: Economic Concerns, Digitalization, And Productivity. Demirtaş, D., Bozkurt, V., \& Yorgun, S. (eDITÖRLER), The COVID-19 Pandemic and Its Economic, Social, and Political Impacts içinde, 87-106.

DOĞAN, M. M. \& DÜZEL, B. (2020). Covid-19 Özelinde Korku-Kaygı Düzeyleri. Electronic Turkish Studies, 15(4). 739-752. https://dx.doi.org/10.7827/TurkishStudies. 44678.

LADIKKLİ, N., BAHADIR, E., YUMUŞAK, F. N., AKKUZU, H., KARAMAN, G., \& TÜRKKAN, Z. (2020). Kovid-19 Korkusu
Ölçeği’nin Türkçe Güvenirlik ve Geçerlik Çalışması. International Journal of SocialScience, 3(2), 71-80.

NGUYEN, M. H. (2021). Factors Influencing Home-Based Telework in Hanoi (Vietnam) During and After The COVID-19 Era. Transportation, 1-32.

ÖZEN, E., GRIMA, S., \& HAMARAT, B. (2021). Teleworking and Emotional Experience and Wellbeing: The Case in the Turkish Financial Services Industry During COVID-19. Scientific Annals of Economics and Business. 68(3), 345-360. DOI: 10.47743/saeb2021-0016.

SATICI, B., GOCET-TEKIN, E., DENIZ, M. E., \&SATICI, S. A. (2020). Adaptation of the Fear of COVID-19 Scale: Its association with psychological distress and life satisfaction in Turkey. International journal of mental health and addiction, 1-9.

SÜMBÜLOĞLU, K. \& AKDAĞ B. (2007). Regresyon Yöntemleri ve Korelasyon Analizi. Hatipoğlu Yayın evi, 73-80, Ankara. 